Al-Uqud: Journal of Islamic Economics E-ISSN 2548-3544, P-ISSN 2549-0850 Accredited No. 28/E/KPT/2019
Volume 4 Issue 2, July 2020

DOI:10.26740/al-uqud.v4n2.p208-217

Page 208-217

\title{
How Islamic Bank Managing Risk? An Emphasis on Anticipating Financial Crisis
}

\author{
Sebastiana Viphindrartin ${ }^{1}$ Zainuri $^{2 *}$, Muhammad Zilmi Anugrah ${ }^{3}$ \\ 1,2,3 Department of Economics, Faculty of Economics and Business, Universitas \\ Jember. Jalan Kalimantan No.37, Jember 68121, Indonesia.
}

\begin{abstract}
The global economic crisis in 2008 shocked and pressured Indonesian macroeconomic and financial system stability. The decline in macroeconomic stability has an impact on banking policy in lending. Most banks in the world respond to the crisis by doing credit rationing, but how about Islamic bank response toward this condition in Indonesia? Therefore, this study aims to examine the effect of Capital Adequacy Ratio $(C A R)$ and macroeconomic variables on the amount of Islamic banking financing in Indonesia. The method used in this study is the SVAR (Structural Vector Auto Regression) analysis method. The results showed that inflation, capital, and CAR variables had a significant effect on Islamic bank's financing amount. In contrast, GDP had no significant impact on Islamic bank's financing amount which means that Islamic banking in Indonesia was not implemented pro-cyclical based lending policy.
\end{abstract}

Keywords: Macroeconomic variable; Financing; SVAR; Pro-cyclical

Paper type: Research paper

*Corresponding author: zainuri.feb@unej.ac.id

Received: September 13, 2019; Accepted: January 16, 2020; Published: July 01, 2020

Cite this document: Viphindrartin, S., Zainuri, \& Anugrah., M., Z. (2020). How Islamic Bank Managing Risk? An Emphasis on Anticipating Financial Crisis. Al-Uqud: Journal of Islamic Economics, 4(2), 208-217. doi: http://dx.doi.org/10.26740/al-uqud.v4n2.p208-217

Copyright (C) 2020, Al-Uqud: Journal of Islamic Economics http://journal.unesa.ac.id/index.php/jie 


\begin{abstract}
Abstrak: Krisis ekonomi global yang terjadi pada tahun 2008 memberikan guncangan dan tekanan terhadap stabilitas makro ekonomi dan sistem keuangan. Menurunnya stabilitas makro ekonomi berdampak terhadap sikap perbankan dalam menyalurkan kredit. Sebagian besar perbankan di dunia merespon situasi krisis dengan melakukan penjatahan kredit, akan tetapi bagaimana respon perbankan syariah di Indonesia? Penelitian ini bertujuan untuk menguji pengaruh Capital Adequacy Ratio (CAR) dan variabel makroekonomi terhadap jumlah pembiayaan perbankan syariah di Indonesia. Metode yang digunakan dalam penelitian ini adalah metode analisis SVAR (Structural Vector Autoregression). Hasil penelitian menunjukkan variabel inflasi, modal dan CAR berpengaruh signifikan, sedangkan GDP tidak berpengaruh signifikan yang berarti perbankan syariah di Indonesia tidak bersifat pro siklis.
\end{abstract}

Kata kunci: Makroekonomi; Pembiayaan; SVAR; Pro Siklis

\title{
INTRODUCTION
}

The world economic conditions have experienced several crises that hit the world economy. One of which is global financial crisis in 2008 that significantly impacted the global economy and exacerbate the level of bad loans and spread to the globally integrated financial system. This condition is not only shock financial sector but also to the real sector through various mechanisms. Hence, it implied the urgency of maintaining financial system stabilization to avoid the large costs of rescue caused by the financial crisis (Demirbas, 2017). Meanwhile, macroeconomic policies that affect the economic cycle and business cycle in the future are created as an effort to anticipate any financial risk. It is because, the country's financial institution as such banks will respond to any financial cycle or turbulence such as economic recession by reducing credit or known as credit rationing (Cowling, 2010).

The availability of credit influenced by bank management that adjust the economy circumstances. Bank's management prefers risk-averse behavior when they have limitations in diversifying and distributing risk. In the condition of having limited level of capital, banks face risks such as non-performing loans, liquidity risk, and other risks that related to economic or non-economic factors (İncekara et al., 2019). Credit growth is one of the best predictor of economic condition both in expansionary or recession condition (financial instability) in a country (Jordà et al., 2011). Almost all banks in the world implemented in a pro-cyclical nature which tends to reduce their lending during periods of economic downturn. This policy is restrained it in both private and public banks which private banks are more reactive to interest rates changes and business cycle conditions (Chavan et al., 2019).

Meanwhile, when the economy is expanding exponentially that indicated by GDP growth and bank's high credit level of both Islamic banks and conventional banks (Ascarya et al., 2016). Any turmoil that occurs in macroeconomic conditions will affect credit and economic activity as a whole. This condition causes banks to prefer risk-averse management. Some research on the pro-cyclicality of banking in various parts of the world has been carried out by (Foos et al., 2010), (Jeong, 2010), (Ibrahim, 2016), (Ghosh, 2013), (Kupiec et al., 2013). 
Likewise, with GDP, the inflation rate can also affect the level of credit distribution. The level of lending demand is strongly influenced by economic conditions reflected by the level of inflation. Higher inflation can increase the borrower's capacity to repay loans by reducing the real value of the debt that has not been paid off. But on the other hand, an increase in inflation can also weaken the capacity of borrowers to make loan payments as a result of reduced real income when wages are rigid (Lin et al., 2016). The amount of lending issued by banks as an intermediary is undoubtedly influenced by the availability of funds owned by the bank itself. The capital ratio or CAR (Capital Adequacy Ratio) provides a reference for banks in providing capital decisions in the needs of developing business products and maintaining capital risks that may occur due to banking products and operations such as lending, etc. The CAR ratio illustrates that every form of investment, in the form of credit, for example, will always have or contain risk and will be mitigated by providing capital adjustment to a certain percentage of the investment value. But what about the response was given by Islamic banking in Indonesia?

Ibrahim (2016) who examined the management of bank lending, found that the behavior of conventional banks was more cyclical compared to Islamic banks. Research conducted by Ghosh, (2013), which examined GCC banks from 19962009 , found pro-cyclicality management worsened the condition of conventional banking because credit grew faster than Islamic banks when the economy experienced a period of expansion and had a more moderate impact. On Islamic banks, Ibrahim et al., (2018) using the GMM model, found that Islamic banks continues to greater financing channel compared to conventional banks when the economy is experiencing crisis pressures so that Islamic bank contributes to financial and economic stability.

Besides that, research conducted by Hasan et al., (2011) gives a clue that Islamic banks have better and more stable performance in channeling financing. Khediri et al., (2015) who investigated the features of conventional banks and Islamic banks in Gulf Cooperation Countries (GCC), found that Islamic banks were, on average, more profitable, more liquid, better capitalized, and had lower credit risk than conventional banks. Kabir et al., (2015) questioned the model used in measuring credit risk with Z score and NPL models. It is because these models tend to create a biased value if measuring the credit risk of Islamic banks. Therefore he proposed Merton's distance-to-default model than these models.

On the contrary, the results of the study Bourkhis et al., (2013) did not find differences between Islamic banks and conventional banks in dealing with the financial crisis. Another researcher, Aysan et al., (2018), found evidence that Islamic banks in Turkey did not show significant differences from conventional banks in channeling credit, both were pro-cyclical. Baskaya et al., (2017), who examined the policy framework in Turkey in the post-GFC period, underlined the importance of reformulating monetary policy considering that conventional policies are inadequate, for example, the policy of raising interest rates with the aim of inhibiting credit growth will in fact lead to an explosion of credit through capital inflow. Furthermore, Fakhri (2017) revealed that Islamic banks showed less stable 
performance compared to conventional banks due to moral hazard (corruption) which forced Islamic banks to use non-PLS instruments.

Different from Ascarya et al., (2016) who write the uses OLS, ECM, and ARDL in responding to the business cycle, this study uses the SVAR method by including macroeconomic fundamentals and CAR variables to determine the response of Islamic banks to the wave of the economy. Kupiec et al., (2013) pays more attention to credit risk (NPL) and variables of profitability as determinants of credit distribution. Ghosh, (2013). The sample of this study are GCC banks from 1996-2009 implied pro-cyclical banking behavior that worsened the impact of the economic crisis even though it was rather moderate than Islamic banks. This paper is also different from the findings of Lin et al., (2016) that examines the impact of macroeconomic factors on credit risk in conventional and Islamic banks in Indonesia regardless of the nature of the banking pro-cyclicality. The purpose of this paper is to investigate the behavior of Islamic banking financing in Indonesia in response to the economic cycle that proxied from the GDP variable and Capital Adequacy Ratio (CAR) variable and inflation as part of macroeconomic fundamentals.

\section{RESEARCH METHODS}

The method used to explain the influence of macroeconomic variables and macro prudential instruments on the growth of Islamic banking financing in the short and long term in Indonesia by the Structural Vector Auto Regression (SVAR) method. By uses Islamic bank data in Indonesia from January 2010 to December 2018, the SVAR method uses to answer the problem formulation in this study by the formation of restrictions used in the SVAR estimation model. The restrictions formed based on economic theories combined with empirical facts that have a function to limit the relationship between variables in this study. Furthermore, Structural Vector Auto Regression (SVAR) method is a model developed from the estimation method of Vector Auto Regression (VAR). The method uses to observe the turmoil that occurs in the variable under study and observe the response to the storm in the short and long term. The SVAR model also built to analyze the deterministic movements of the VAR model (Amisano et al., 2012).

The model in this study follows the model based on previous research by Kang et al., (2016), whose model examines the application of macroprudential policies and combines with macroeconomic variables in analyzing credit growth. The specifications of the model used are as follows.

$P P=f(C A R, C A P, I N F, G D P)$

The equation model is then revealed to be the econometric model as follows.

$P P=\beta_{0}+\beta_{1} C A R_{t}+\beta_{2} C A P_{t}+\beta_{3} I N F_{t}+\beta_{4} G D P_{t}+\varepsilon_{t} \ldots$

Further restrictions are formed through inputting variable residuals into VAR models in sequence. The formation of these restrictions can be written as follows.

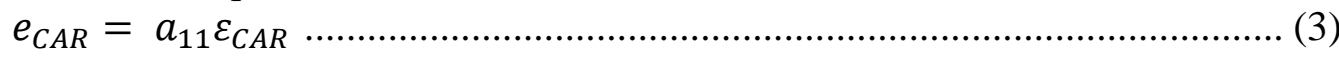

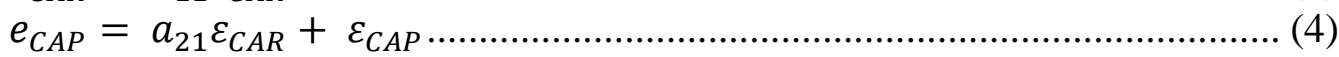

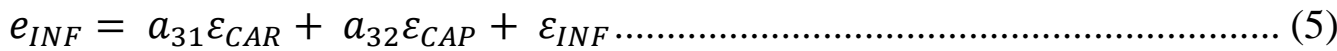

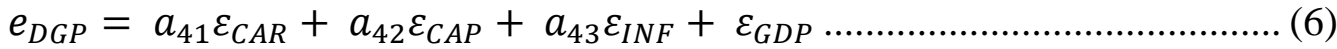

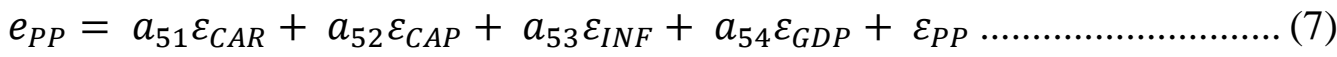


The restrictions that have been formed compile the residual equation as follows.

$$
\left[\begin{array}{c}
e_{C A R} \\
e_{C A P} \\
e_{I N F} \\
e_{G D P} \\
e_{P P}
\end{array}\right]=\left[\begin{array}{ccccc}
1 & 0 & 0 & 0 & 0 \\
a_{21} & 1 & 0 & 0 & 0 \\
a_{31} & a_{32} & 1 & 0 & 0 \\
a_{41} & a_{42} & a_{43} & 1 & 0 \\
a_{51} & a_{52} & a_{53} & a_{54} & 1
\end{array}\right]\left[\begin{array}{c}
\varepsilon_{C A R} \\
\varepsilon_{C A P} \\
\varepsilon_{I N F} \\
\varepsilon_{G D P} \\
\varepsilon_{P P}
\end{array}\right]
$$

Next, the matrix results are converted to the SVAR model in the form @, which can then be used in the SVAR method analysis as follows.

$$
\begin{aligned}
& @ e_{1}=C(1) * @ u_{1} \\
& @ e_{2}=C(2) * @ e_{1}+C(3) * @ u_{2} \\
& @ e_{3}=C(4) * @ e_{1}+C(5) * @ e_{2}+C(6) * @ u_{3} \\
& @ e_{4}=C(7) * @ e_{1}+C(8) * @ e_{2}+C(9) * @ e_{3}+C(10) * @ u_{4} \\
& \quad @ e_{5}=C(11) * @ e_{1}+C(12) * @ e_{2}+C(13) * @ e_{3}+C(14) * @ e_{4}+C(15) * @ u_{5}
\end{aligned}
$$

\section{RESULTS AND DISCUSSION}

The SVAR analysis model in this study is used to explain the variable Capital Adequacy Ratio, inflation, capital, and GDP in influencing the level of financing of Islamic banks. The results of this analysis aim to see the relationship between variables significantly as follows.

Model Restriction Type:

$@ e_{1}=C(1) * @ u_{1}$

$@ e_{2}=C(2) * @ e_{1}+C(3) * @ u_{2}$

$@ e_{3}=C(4) * @ e_{1}+C(5) * @ e_{2}+C(6) * @ u_{3}$

$@ e_{4}=C(7) * @ e_{1}+C(8) * @ e_{2}+C(9) * @ e_{3}+C(10) * @ u_{4}$

$@ e_{5}=C(11) * @ e_{1}+C(12) * @ e_{2}+C(13) * @ e_{3}+C(14) * @ e_{4}+C(15) * @ u_{5}$

where,

@ $e_{1}$ represents $D_{(C A R)}$ residuals

$@ e_{2}$ represents $D_{(C A P I T A L)}$ residuals

$@ e_{3}$ represents $D_{(I N F L A T I O N)}$ residuals

$@ e_{4}$ represents $D_{(D G P)}$ residuals

$@ e_{5}$ represents $D_{(\text {FINANCING })}$ residuals 
Table 1. SVAR Estimation Results

\begin{tabular}{lcccc}
\hline Variable & \multicolumn{1}{c}{ Coefficient } & Std. Error & z-Statistic & Prob. \\
\hline $\mathrm{C}(2)^{* *}$ & 0.007135 & 0.003255 & 2.192113 & 0.0284 \\
$\mathrm{C}(4)$ & 0.049611 & 0.065034 & 0.762845 & 0.4456 \\
$\mathrm{C}(5)^{* *}$ & 4.608833 & 1.942500 & 2.372629 & 0.0177 \\
$\mathrm{C}(7)$ & 0.000352 & 0.002901 & 0.121514 & 0.9033 \\
$\mathrm{C}(8)$ & 0.138504 & 0.088768 & 1.560288 & 0.1187 \\
$\mathrm{C}(9)$ & -0.001492 & 0.004425 & -0.337230 & 0.7359 \\
$\mathrm{C}(11)^{* *}$ & -0.004333 & 0.001793 & -2.416373 & 0.0157 \\
$\mathrm{C}(12)^{*}$ & 0.801309 & 0.055532 & 14.42979 & 0.0000 \\
$\mathrm{C}(13)^{*}$ & 0.008470 & 0.002737 & 3.094401 & 0.0020 \\
$\mathrm{C}(14)$ & 0.040803 & 0.061511 & 0.663348 & 0.5071 \\
$\mathrm{C}(1)^{*}$ & 0.951908 & 0.066976 & 14.21267 & 0.0000 \\
$\mathrm{C}(3)^{*}$ & 0.031137 & 0.002191 & 14.21267 & 0.0000 \\
$\mathrm{C}(6)^{*}$ & 0.607855 & 0.042769 & 14.21267 & 0.0000 \\
$\mathrm{C}(10)^{*}$ & 0.027035 & 0.001902 & 14.21267 & 0.0000 \\
$\mathrm{C}(15)^{*}$ & 0.016712 & 0.001176 & 14.21267 & 0.0000 \\
\hline
\end{tabular}

Remarks $=*$ significant $\alpha(1 \%), * *$ significant $\alpha(5 \%)$

The SVAR estimation test results show that the relationship of each causal variable according to restrictions on the model statistically that has several variables which significantly connected to other variables. The significance of the relationship between variables can be observed by examining probability value with $\alpha$ value equals to $1 \%, 5 \%$, and $10 \%$.

Furthermore, SVAR results show that in the restriction model, if each significant variable is influenced by the variable that reflected by $\mathrm{C}(1), \mathrm{C}(3), \mathrm{C}$ (6), C (10), and C (15) respectively showing variable CAR, Capital, Inflation, GDP and Financing. The results of SVAR analysis for the variable CAR C 11 showed a negative coefficient of -0.004333 with a probability value of 0.0157 or significant at $\alpha=5 \%$, which indicates a direct relationship between CAR and financing. When there is an increase in CAR, it will be followed by a decrease in funding, and vice versa, when there is a decrease in CAR, it will be followed by an increase in funding. Then C 12 (Capital variable) and C 13 (inflation variable) and C 14 (GDP) has a positive coefficient value of $0.801309 ; 0.008470$; and 0.040803 that indicates a direct relationship between variables of capital, inflation, and GDP with financing issued by Islamic banking. Capital and inflation variables have a significant effect on financing with a significance level of $1 \%$, meaning that each increase in the two variables will be followed by an increase in financing. On the other hand, the GDP variable does not have a significant effect so an increase or decrease in GDP will not be followed by an increase or decrease in financing.

Capital variable C (12) has a significant relationship with Islamic banking financing in Indonesia. The estimation results that show the relationship between capital and financing are following the findings of research conducted by Baskaya et al., (2017), which explains that banks will increase credit supply when capital inflows are higher. Meanwhile, C (13)/inflation variable, has a significant influence on financing with a probability value of 0.0020 or significant at $\alpha=1 \%$. There is a relationship between inflation and financing following the research conducted by 
(Bitar et al., 2018), which explains that the financing decision or capitalization of Islamic banks is influenced by the economic and financial environment and market conditions. Although the capital decisions of Islamic banks refer to Islamic law, the role of a stable economic system will increase bank capitalization and reduce the risk of the financial sector. Ibrahim, (2016) shows different findings in which Islamic banking financing decisions are not influenced by the business cycle. Meanwhile, the inflation variable is proxied by pro-cyclical consumer price index.

The estimation results of CAR variables that show a negative and significant relationship between CAR and Islamic banking financing are in line with Yuanyan, (2017) who conducted research in the euro area banking. The bank capital costs are the most effective variable in slowing mortgage lending growth, and that the impact is transmitted mainly through price margins and the same banking channels as monetary policy. In line with that, research from Louati et al., (2015) explains that funding ratios have a significant impact on the behavior of Islamic banking. In contrast to the findings of the two researchers, Shaw et al., (2013) found that increasing capital ratios did not always reduce the number of loans provided by banks. It is provided that they were able to combine their equity financing by accumulating more equity instead of reducing loans. Meanwhile, the strong influence of GDP variables on bank financing is in line with research conducted by Ibrahim et al., (2018), which explains that the growth of Islamic bank financing actually increased during the crisis period.

This growth is higher than in conventional bank's credit growth. This shows that the shock of the real economy, which can be seen from the GDP growth rate, does not significantly affect financing growth. The results of Fungáčová et al., (2013) show a decrease in credit during the crisis period in Russia. This is supported Leroy et al., (2019) which shows that actual deviations of GDP from potential GDP cause greater credit fluctuations in countries when bank's competition is weak. The pro-cyclical nature is seen when monopolistic banking tends to provide cheaper credit during booms and more expensive during recessions. Aysan et al., (2018) studied macroeconomic shocks and Islamic bank behavior in Turkey which found that Islamic banks are as pro-cyclical as conventional banks. However, Islamic banks are more able to control excessive financing when experience growth (wealth) condition. The 2008-2009 crisis gave a different impact on credit growth between conventional banks and Islamic banks, where Islamic banks showed better performance (Hasan et al., 2011).

The influence of significant inflation variables on Islamic bank financing in this paper reinforces the finding Lin et al., (2016) that inflation has a positive and negative effect on conventional bank credit risk. Ghosh, (2015), who examined in 50 US states and the District of Columbia from 1984-2013, noted the inflation variable as the main determinant of credit risk (NPL). The Çatik et al., (2012) also found that credit volumes do not fluctuate in low inflation regimes.

The study also found that the GDP variable had no significant effect on Islamic bank financing in Indonesia. Moreover, lending does not depend on business cycle conditions that reflected in GDP's fluctuation. This fact is different from the nature of banking that will increase their lending volume when the economy increases and vice versa (pro-cyclical) (Foos et al., 2010), (Ibrahim, 
2016). This situation indicates that Islamic banks in Indonesia are not pro-cyclical. This finding is in line with the results of Beck et al., (2010), Abdelaziz, (2010), Čihák et al., (2010), which confirms precisely the increase in credit during a crisis period. Although there are some researchers who find that Islamic banks are equally pro-cyclical with conventional banks. Aysan et al., (2018) or other findings which state that the resilience of Islamic banks only occurs at the beginning of a crisis period and worsens in the next period (Alqahtani et al., 2017). Nevertheless, in general, this paper finds that Islamic banks are safer and have lower credit risk because they are not pro-cyclical. This statement is reinforced by research findings by (Kabir et al., 2015) and (Fakhfekh et al., 2014) using Merton's distance-todefault (DD) model as an instrument to measure credit risk.

\section{CONCLUSION}

SVAR estimation results show a significant relationship between Islamic bank financing with macroeconomic fundamentals in Indonesia. Capital and inflation variables show a significant effect on Islamic banking financing in Indonesia. In contrast, the results of GDP testing do not show a significant impact. This shows that Islamic banking in Indonesia is not pro-cyclical and safer from deeper crisis shocks. This paper has not included macroprudential variables as determinants of financing. Researchers can then include conventional banks as a comparison of behavior in facing the business cycle.

\section{REFERENCES}

Abdelaziz, C. (2010). Risk exposure during the global financial crisis: the case of Islamic banks. International Journal of Islamic and Middle Eastern Finance and Management, 3(4), 321-333. https://doi.org/10.1108/17538391011093261

Alqahtani, F., Mayes, D. G., \& Brown, K. (2017). Reprint of Economic turmoil and Islamic banking: Evidence from the Gulf Cooperation Council. Pacific-Basin Finance Journal, 42 , 113-125. https://doi.org/https://doi.org/10.1016/j.pacfin.2016.06.013

Amisano, G., \& Giannini, C. (2012). Topics in structural VAR econometrics. Springer Science \& Business Media.

Ascarya, Rahmawati, S., \& Karim, A. A. (2016). Testing of the Procyclicality of Islamic and Conventional Banks in Indonesia. Macroprudential Regulation and Policy for the Islamic Financial Industry, October 2015, 133-152. https://doi.org/10.1007/978-3-319-30445-8_8

Aysan, A. F., \& Ozturk, H. (2018). Does Islamic banking offer a natural hedge for business cycles? Evidence from a dual banking system. Journal of Financial Stability, 36, 22-38. https://doi.org/10.1016/j.jfs.2018.02.005

Baskaya, Y. S., di Giovanni, J., Kalemli-Özcan, Ş., Peydro, J. L., \& Ulu, M. F. (2017). Capital flows and the international credit channel. In Journal of International Economics (Vol. 108, pp. S15-S22). https://doi.org/10.1016/j.jinteco.2016.12.003

Beck, T., Demirgüç-Kunt, A., \& Merrouche, O. (2010). Islamic vs. conventional banking: Business model, efficiency and stability. The World Bank. 
Bitar, M., Kabir Hassan, M., \& Hippler, W. J. (2018). The determinants of Islamic bank capital decisions. Emerging Markets Review, 35, 48-68. https://doi.org/10.1016/j.ememar.2017.12.002

Bourkhis, K., \& Nabi, M. S. (2013). Islamic and conventional banks' soundness during the 2007-2008 financial crisis. Review of Financial Economics, 22(2), $68-77$.

Çatik, A. N., \& Karaçuka, M. (2012). The bank lending channel in Turkey: has it changed after the low-inflation regime? Applied Economics Letters, 19(13), 1237-1242. https://doi.org/10.1080/13504851.2011.619479

Chavan, P., \& Gambacorta, L. (2019). Bank lending and loan quality: an emerging economy perspective. Empirical Economics, 57(1), 1-29. https://doi.org/10.1007/s00181-018-1436-5

Čihák, M., \& Hesse, H. (2010). Islamic banks and financial stability: An empirical analysis. Journal of Financial Services Research, 38(2-3), 95-113.

Cowling, M. (2010). The role of loan guarantee schemes in alleviating credit rationing in the UK. Journal of Financial Stability, 6(1), 36-44.

Demirbas, E. (2017). Macroeconomic Impact of 2008 Financial Crisis on Countries by Income Groups. Nile Journal of Business and Economics, 2(4), 57-69.

Fakhfekh, M., \& Hachicha, N. (2014). Return volatilities and contagion transmission between Islamic and conventional banks throughout the subprime crisis: evidence from the DCC-MGARCH model. International Journal of Managerial and Financial Accounting 2, 6(2), 133-145.

Fakhri, K. (2017). Regulatory capital and stability of Islamic and conventional banks. International Journal of Islamic and Middle Eastern Finance and Management, 10(3), 312-330. https://doi.org/10.1108/IMEFM-06-20160079

Foos, D., Norden, L., \& Weber, M. (2010). Loan growth and riskiness of banks. Journal of Banking \& Finance, 34(12), 2929-2940.

Fungáčová, Z., Herrala, R., \& Weill, L. (2013). The influence of bank ownership on credit supply: Evidence from the recent financial crisis. Emerging Markets Review, 15, 136-147.

Ghosh, A. (2015). Banking-industry specific and regional economic determinants of non-performing loans: Evidence from US states. In Journal of Financial Stability (Vol. 20, pp. 93-104). https://doi.org/10.1016/j.jfs.2015.08.004

Ghosh, S. (2013). Funding structure, procyclicality and lending: evidence from GCC banks. Review of Middle East Economics and Finance, 9(2), 241-270.

HASAN, M., \& DRIDI, J. (2011). the Effects of the Global Crisis on Islamic and Conventional Banks: a Comparative Study. Journal of International Commerce, Economics and Policy, 02(02), 163-200. https://doi.org/10.1142/s1793993311000270

Hasan, M. M., \& Dridi, J. (2010). The effects of the global crisis on Islamic and conventional banks: A comparative study. IMF Working Papers, 1-46.

Ibrahim, M. H. (2016). Business cycle and bank lending procyclicality in a dual banking system. Economic Modelling, 55, 127-134. 
Ibrahim, M. H., \& Rizvi, S. A. R. (2018). Bank lending, deposits and risk-taking in times of crisis: A panel analysis of Islamic and conventional banks. Emerging Markets Review, 35, 31-47.

İncekara, A., \& Çetinkaya, H. (2019). Liquidity Risk Management: A Comparative Analysis of Panel Data Between Islamic And Conventional Banking In Turkey. Procedia Computer Science, 158, 955-963. https://doi.org/10.1016/j.procs.2019.09.136

Jeong, H. (2010). The procyclicality of bank lending and its funding structure: The case of Korea.

Jordà, Ò., Schularick, M., \& Taylor, A. M. (2011). Financial Crises, Credit Booms, and External Imbalances: 140 Years of Lessons. IMF Economic Review, 59(2), 340-378. https://doi.org/10.1057/imfer.2011.8

Kabir, M. N., Worthington, A., \& Gupta, R. (2015). Comparative credit risk in Islamic and conventional bank. Pacific-Basin Finance Journal, 34, 327-353.

Kang, D., \& Mason, A. (2016). Macroprudential Regulation of International Finance: Managing Capital Flows and Exchange Rates. Edward Elgar Publishing.

Khediri, K. Ben, Charfeddine, L., \& Youssef, S. Ben. (2015). Islamic versus conventional banks in the GCC countries: A comparative study using classification techniques. Research in International Business and Finance, 33, 75-98.

Kupiec, P. H., Lee, Y., \& Rosenfeld, C. (2013). Macroprudential policies and the growth of bank credit. American Enterprise Institute Working Paper, 8.

Leroy, A., \& Lucotte, Y. (2019). Competition and credit procyclicality in European banking. In Journal of Banking and Finance (Vol. 99, pp. 237-251). https://doi.org/10.1016/j.jbankfin.2018.12.004

Lin, H.-Y., Farhani, N. H., \& Koo, M. (2016). The Impact of Macroeconomic Factors on Credit Risk in Conventional Banks and Islamic Banks: Evidence from Indonesia. International Journal of Financial Research, 7(4), 105-116.

Louati, S., Abida, I. G., \& Boujelbene, Y. (2015). Capital adequacy implications on Islamic and non-Islamic bank's behavior: Does market power matter? Borsa Istanbul Review, 15(3), 192-204.

Shaw, M., Chang, J., \& Chen, H.-J. (2013). Capital adequacy and the bank lending channel: Macroeconomic implications. Journal of Macroeconomics, 36, 121137.

Yuanyan, Z. (2017). Effectiveness and channels of macroprudential policies: lessons from the Euro area. Journal of Financial Regulation and Compliance, 25(3), 271-306. https://doi.org/10.1108/JFRC-10-2016-0094 